\title{
Dermatology
}

Dermatology 2008;217:199-200

DOI: $\underline{10.1159 / 000141650}$

\section{Cutaneous Lymphoid Hyperplasia on a Preexistent Melanocytic Nevus}

\section{A. Dadban ${ }^{\mathrm{a}}$, F. Truchetet ${ }^{\mathrm{b}}$}

a Department of Dermatology, Amiens University Hospital, Amiens, and ${ }^{b}$ Department of Dermatology, Metz-Thionville General Hospital, Metz, France

\section{Key Words}

Cutaneous lymphoid hyperplasia $\cdot$ Cutaneous pseudolymphoma

\section{Introduction}

Cutaneous lymphoid hyperplasia $(\mathrm{CLH})$ is defined by a polymorphic proliferation of $\mathrm{B}$ and $\mathrm{T}$ cells, organized in structures similar to lymphatic follicles [1]. In the published cases, there have not been any preexistent lesions. We describe the first report of $\mathrm{CLH}$ on a preexistent melanocytic nevus.

\section{Case Report}

An 83-year-old man had had a painful growth on his back for a month. He did not remember any trauma, insect bites or preexistent lesions at the site. His medical history was significant for type II diabetes, hypercholesterolemia, myocardial infarction and coronary bypass surgery. He had been taking gliclazide for 2 months, and sotalol, potassium, furosemide, aspirin and simvastatin for several years. Clinically, there was a 5-cm inflammatory, erythematous nodule on the back. The nodule was homogenous, and no pigmented lesion was noticed clinically. Incisional biopsy showed a normal epidermis, a dermal cell population made of small nests of pigmented cells, and a dense dermal infiltrate composed of small lymphocytes (fig. 1, 2). The pigmented cells were $\mathrm{S}-100$ protein positive, and the lymphocytes were predominantly CD20-positive (B) cells. There were also a few small, CD3-positive lymphocytes at the periphery. The lymphocytic infiltrate did not dissociate nevus nests. The nevus had been completely excised with the biopsy. Borrelia burgdorferi-specific antibodies were negative. Nevertheless, in the hypothesis of borrelial lymphocytoma, a 15-day course of doxycycline was prescribed. The remaining nodule disappeared within 2 months.

\section{Comments}

CLH can be idiopathic or arise subsequent to a number of antigenic stimuli, of which the most frequently cited are insect bites, ectoparasitoses (as scabies), tattoos, vaccinations, foreign bodies (as piercing material) and drug ingestion, including herbal medi-

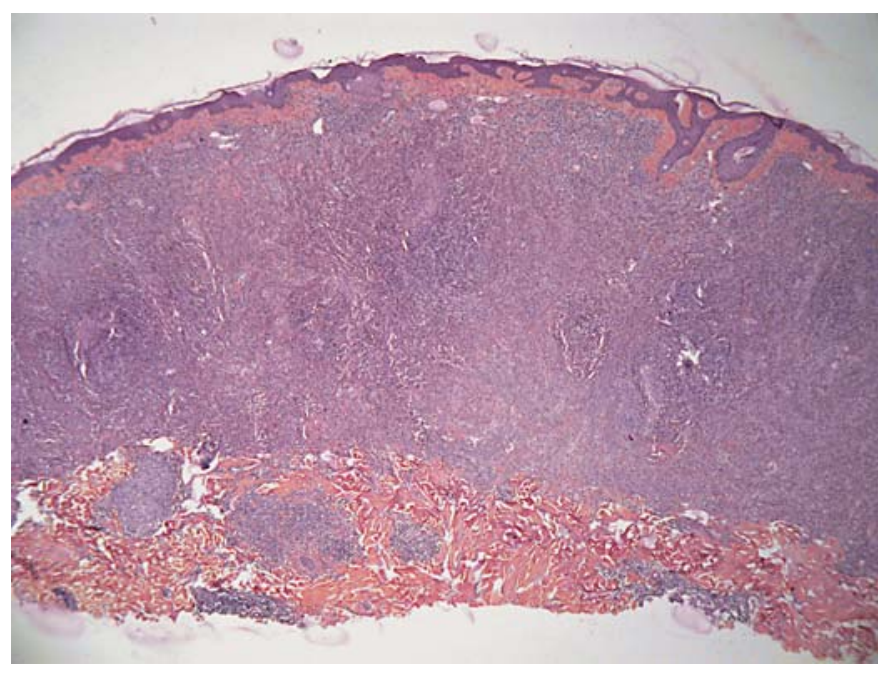

Fig. 1. Incisional biopsy of a back lesion. $\times 2.5$.

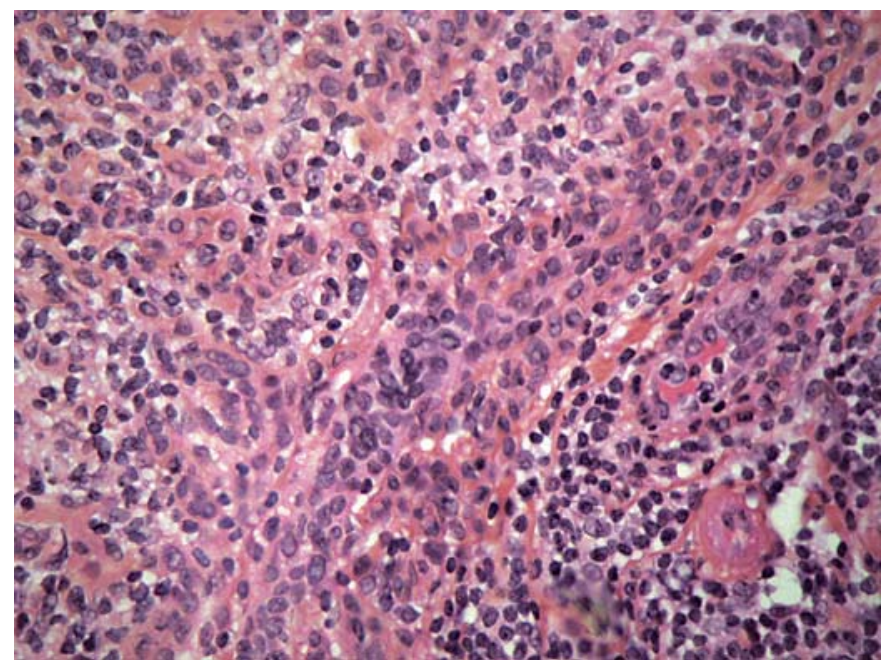

Fig. 2. Nevus nests with dense lymphocytic infiltrate. $\times 40$.

cine [2]. Depending on the geographic zone, B. burgdorferi infection may be a common etiology. Although a borrelial etiology (as may be suggested by the response to antibiotics) or an idiopathic CLH with a purely coincidental adjacent nevus could not be eliminated, the presence of a melanocytic nevus in the biopsy mate-

\section{KARGER}

(C) 2008 S. Karger AG, Basel

Fax +41613061234 E-Mail karger@karger.ch www.karger.com 
rial, and the complete regression of CLH after the excision of the nevus suggest a cause-and-effect relationship. We postulate that nevus cells had become antigenic, in a similar way as in Sutton's phenomenon [3] or in melanoma-associated vitiligo [4], albeit with a different histological reaction in CLH. In both phenomena, a preexistent melanocytic lesion becomes antigenic with no apparent reason. The role of antimelanocyte T cells [5] could be suspected. Finally, the drug gliclazide as well as its family, started a month before the appearance of the lesion, are not known to induce CLH-like lesions. The lesion subsided while gliclazide was continued. In the event of relapse, this drug's etiological role should be considered.

\section{Conclusion}

We believe our report to be the first describing coexistent nevus and CLH. This rare event, as well as being troublesome from the histological viewpoint, could represent a peculiar form of immunological reaction to melanocytes, hitherto unknown.

\section{References}

1 Nihal M, Mikkola D, Horvath N, Gilliam AC, Stevens SR, Spiro TP, Cooper KD, Wood GS: Cutaneous lymphoid hyperplasia: a lymphoproliferative continuum with lymphomatous potential. Hum Pathol 2003;34:617-622.

2 Meyer S, Vogt T, Obermann EC, Landthaler M, Karrer S: Cutaneous pseudolymphoma Induced by Cimicifuga racemosa. Dermatology 2007;214:94-96.

3 Brandt O, Christophers E, Fölster-Holst R: Halo dermatitis followed by the development of vitiligo associated with Sutton's nevi. J Am Acad Dermatol 2005;52(suppl 1):S101-S104.

4 Daneshpazhooh M, Shokoohi A, Dadban A, Raafat J: The course of melanoma-associated vitiligo: report of a case. Melanoma Res 2006; 16:371-373.

5 Musette P, Bachelez H, Kourilsky P, Dubertret L, Gachelin G: What is the best way to define the antimelanocyte $\mathrm{T}$ cell repertoire? J Invest Dermatol 1999; 113:286-288.

Dr. Ali Dadban

Service de Dermatologie, Centre Hospitalier Universitaire d'Amiens Avenue René-Laënnec

FR-80054 Amiens Cedex 1 (France)

Tel. +33 3224558 41, Fax +33 322455794

E-Mail alidadban@gmail.com 